\section{Zuriah}

Jurnal Pendidikan Anak Usia Dini
Volume 1, Nomor 2, 2020

ISSN 2746-0797 (p), 2746-0800 (e)

http://journal.iaincurup.ac.id/index.php/paud

DOI: $10.29240 /$ zuriah.v1i2.2020 | p. $97-106$

\title{
Manajemen Mutu Pendidikan Anak Usia Dini Wijaya Kusuma Rejang Lebong
}

\author{
Murni Yanto \\ Institut Agama Islam Negeri Curup, Indonesia \\ yantomurni.65@gmail.com
}

\begin{abstract}
This study aimed to discribe the application of management of Early Childoon Education in Wijaya Kusuma, jalan Suprapto, Talang Rimbo Baru, Curup Tengah District, Rejang Lebong Regency, Bengkulu. This tyfe of research is a qualitatifve descriptive study by taking a teacher at the wijay a Ealy Childhood Education Park Kusuma as the object of research. The data collection technique was carried out using structured interviews. The results showed that the Wijaya Kusuma Early Childhood Education Park had met management standards, namely (a) Planning, all institutational activities concerning what to do,where to do it,when it will be done, (b) Organization,planned to be compeleted by members of the work group, determining the work relationship between them and providing the appropriate work environment. (c) Direction, is the encouragement that will provide motivation in an organization. (d) Supervision to determine the realization of personnel behavior in educational organizations and whether the level of attainment of educational goals is as desired. Supervision is carried out to collect data on the implementation of cooperation between tearhers, principals, counselors. (e) The quality of services provided to steakholders consisting of students, alumni and old school student.
\end{abstract}

Keywords: Management, Quality, Education, Early Childhoon, Education Early Childhood

\begin{abstract}
Abstrak
Penelitian ini bertujuan untuk mengetahui gambaran penerapan manajemen Mutu Pendidikan Anak Usia Dini Wijaya Kusuma Jalan Suprapto kelurahan Talang Rimbo Baru Kecamatan Curup Tengah Kabupaten Rejang Lebong Bengkulu. Jenis penelitian yang dilakukan adalah penelitian deskriptif kualitatif dengan mengambil salah satu guru di Taman Pendidikan Anak Usia Dini Wijaya Kusuma sebagai objek penelitian.Teknik pengumpulan data dilakukan dengan menggunakan wawancara terstruktur. Hasil penelitian menunjukean babwa Taman Pendidikan Anak Usia Dini Wijaya Kusuma telab memenubi dalam standar manajemen yaitu: (a) Perencanaan, selurub aktivitas lembaga yang menyangkut apa yang harus dikerjakan, dimana dikerjakan, kapan akan dikerjakan, siapa yang mengerjakan dan bagaimana bal tersebut dikerjakan.(b)
\end{abstract}


Organisasi, direncanakan untuk diselesaikan oleh anggota kelompok pekerjaan, penentuan bubungan pekerjaan diantara mereka dan pemberian lingkungan pekerjaan yang sepatutnya. (c) Pengarahan, merupakan dorongan yang akan memberikan motivasi dalam suatu organisasi.(d) Pengawasan untuk mengetahui realisasi perilaku personil dalam organisasi pendidikan dan apakah tingkat pencapaian tujuan pendidikan sesuai dengan yang dikehendaki. Pengawasan dilakukan untuk. mengumpul data tentang penyelenggaraan kerjasama antar guru, kepala sekolah, konselor. (e) Mutu layanan yang diberikan kepada pemangku kepentingan terdiri dari siswa, alumni dan orang tua siswa PAUD

Kata Kunci: Manajemen, Mutu, Pendidikan, Anak Usia Dini, Pendidikan Anak Usia Dini.

\section{A. PENDAHULUAN}

Undang-Undang Nomor 20 tahun 2003 maka sistem Pendidikan di Indonesia terdiri dari pendidikan anak usia dini, pendidikan dasar, pendidikan menengah, dan pendidikan tinggi, yang keseluruhannya merupakan kesatuan yang sistematik. Pendidikan anak usia dini diselenggarakan sebelum jenjang pendidikan dasar. Pendidikan anak usia dini pada jalur pendidikan formal, non formal, dan/atau informal. Pendidikan anak usia dini pada jalur pendidikan formal terbentuk taman kanak-kanak (TK), Raudhatul atfhal (RA), atau bentuk lain yang sederajat. Pendidikan anak usia dini pada jalur pendidikan nonformal terbentuk kelompok bermain (KB), taman penitipan anak (TPA), atau bentuk lain yang sederajat. Pendidikan pada anak usia dini pada jalur pendidikan informal berbentuk pendidikan keluarga atau pendidikan yang diselenggarakan oleh lingkungan.

Pendidikan anak usia dini merupakan pendidikan yang sangat mendasar dan strategis dalam pembangunan sumber daya manusia. Sesuai pasal 28 undang-undang Nomor 20 tahun 2003 tentang sistem pendidikan Nasional. Pendidikan anak usia dini telah ditempatkan sejajar dengan pendidikan lainnya. Hal ini menunjukkan bahwa secara yuridis formal, pendidikan anak usia dini merupakan bagian yang tak terpisahkan dari keseluruhan sistem pendidikan Nasional. Walau pendidikan pra sekolah bukan merupakan kewajiban dan pra syarat untuk memasuki sekolah dasar.

Menurut Undang-Undang no 20 tahun 2003 tentang sistem pendidikan Nasional, khususnya pasal 1 butir 14, disebutkan bahwa PAUD adalah suatu upaya pembinaan yang ditujukan kepada anak sejak lahir sampai dengan usia 6 tahun yang dilakukan melalui pengasuhan, 
pembimbingan dan pendidikan untuk membantu pertumbuhan dan perkembangan anak agar memiliki kesiapan dalam memasuki pendidikan lebih lanjut (Agus Wibowo, 2012). Pendidikan nasional berpungsi mengembangkan kemampuan dan membentuk watak serta peradaban bangsa yang martabat dalam rangka mencerdaskan kehidupan bangsa, bertujuan untuk berkembangnya potensi peserta didik agar menjadi manusia yang beiman dan bertaqwa kepada Tuhan Yang Maha esa, akhlak mulia,sehat,berilmu, cakep, mandiri dan menjadi warga Negara yang demokratis serta bertanggung jawab (Yanto., 2017). Pendidikan merupakan: Proses dimana seseorang mengembangkan kemampuan sikap dan bentuk-bentuk tingkah laku lainnya dalam masyarakat dimana dia hidup, proses sosial dimana orang dikontrol,sehingga kemampuan sosial dan kemampuan individu yang optimal (Yanto., 2017).

Manajemen menurut etimologi berasal dari bahasa inggris "management" yang dikembangkan dari kata "to manage"yang berarti mengatur atau mengelola. Kata manage ini ini sendiri berasal dari italia "menegglo" yang diadopsi dari bahasa latin "Management" "managlare" yang berasal dari kata manus yang artinya tangan (Tim Dosen administrasi Dosen UPI,2011).Kamus besar bahasa Indonesia "managemen" mempunyai pengertian sebagai penggunaan sumber daya secara efektif untuk mencapai sasaran (Yuku,2013). Manajemen berasal dari bahasa Inggris management yang berarti tata laksana, tata pimpinan dan tata pengelola. Artinya manajemen adalah sebagai suatu proses yang diterapkan oleh individu atau kelompok dalam upaya-upaya koordinasi untuk mencapai tujuan (Awaludin Pimay, 2013). Manajemen merupakan serangkaian kegiatan yang didesain untuk mencapai tujuan organisasi dengan menggunakan sumber daya secara efisien dan efektif dilakukan dalam lingkungan yang senantiasa berubah dari waktu ke waktu (Yanto, 2018).

Kepala pendidikan anak usia dini sebagai pemimpin dilembaganya,maka dia harus mampu membawa lembaganya kearah tercapainya tujuan yang telah ditetapkan, dia harus mampu melihat adanya perubahan serta mampu melihat masa depan dalam kehidupan gelobalisasi yang lebih baik.Kepala sekolah harus bertanggung jawab atas kelancaran dan keberhasilan suatu urusan pengaturan dan pengelolahan secara formal kepada atasannya atau informal kepada masyarakat yang telah menitipkan anak didiknya (Yanto., 2020). Kepala sekolah(PAUD) 
harus mampu melahirkan gagasan yang inovatif yang berguna untuk menghasilkan alternatif kebijakan dalam membangun (Yanto, M., \& Fathurrochman, 2019). Pendidikan memegang peranan penting bagi suatu bangsa,sebab melalui proses pendidikan akan melahirkan manusia yang berkualitas yang akan menentukan kualitas bangsa (Yanto, 2017)

\section{B. METODE PENELITIAN}

Penelitian kualitatif sebagai metode penelitian ilmu-ilmu sosial yang mengumpulkan dan menganalisis data berupa kata-kata (lisan maupun tulisan) dan perbuatan-perbuatan manusia serta peneliti tidak berusaha menghitung atau mengkuantifikasikan data kualitatif yang telah diperoleh dan dengan demikian tidak menganalisis angka-angka.Data yang dianalisis dalam penelitian kaulitatif adalah kata-kata dan perbuatan manusia (Afrizal, 2015). Penelitian merupakan hal dapat dilakukan dalam ilmu-ilmu sosial,dimana penelitian digunakan secara orisinil (Yanto, M., \& Fathurrochman, 2019).

\section{HASIL DAN PEMBAHASAN}

Manajer organisasi,manusia dalam organisasi tidak terlepas dari system yang telah dibuat diorganisasi tersebut.Sistem itu dibuat berdasarkan kesepakatan anggotanya.manajer organisasi ialah yang paling berperan dalam pembentukan system tersebut,oleh karena seorang manajer diharapkan orang yang berwawasan luas dan mampu mengelola organisasi (Yanto., 2020). Manajemen adalah serangkaian kegiatan yang didesain untuk mencapai tujuan organisasi dengan menggunakan sumber daya secara efisien dan efektif dan dilakukan dalam lingkungan yang senantiasa berubah dari waktu ke waktu. Efektif berarti tercapai tujuan yang ditetapkan dan efisien berarti mencapai tujuan dengan menggunakan sedikit mungkin sumber daya yang tersedia. Menurut Piaget dalam Mgs. Nazarudin (2007:163) manajemen adalah serangkaian kegiatan yang didesain untuk mencapai tujuan organisasi dengan menggunakan sumber daya secara efisien dan efektif dan dilakukan dalam lingkungan yang senantiasa berubah dari waktu ke waktu. Efektif berarti tercapai tujuan yang ditetapkan dan efisien berarti mencapai tujuan dengan menggunakan sedikit mungkin sumber daya yang tersedia. 
Menurut Piaget dalam Mgs. Nazarudin (2007:163) manajemen adalah serangkaian kegiatan yang didesain untuk mencapai tujuan organisasi dengan menggunakan sumber daya secara efisien dan efektif dan dilakukan dalam lingkungan yang senantiasa berubah dari waktu ke waktu. Efektif berarti tercapai tujuan yang ditetapkan dan efisien berarti mencapai tujuan dengan menggunakan sedikit mungkin sumber daya yang tersedia. Menurut Piaget dalam Mgs. Nazarudin (2007:163) manajemen adalah serangkaian kegiatan yang didesain untuk mencapai tujuan organisasi dengan menggunakan sumber daya secara efisien dan efektif dan dilakukan dalam lingkungan yang senantiasa berubah dari waktu ke waktu. Efektif berarti tercapai tujuan yang ditetapkan dan efisien berarti mencapai tujuan dengan menggunakan sedikit mungkin sumber daya yang tersedia.

Menurut Piaget dalam Mgs. Nazarudin (2007:163) manajemen adalah serangkaian kegiatan yang didesain untuk mencapai tujuan organisasi dengan menggunakan sumber daya secara efisien dan efektif dan dilakukan dalam lingkungan yang senantiasa berubah dari waktu ke waktu. Efektif berarti tercapai tujuan yang ditetapkan dan efisien berarti mencapai tujuan dengan menggunakan sedikit mungkin sumber daya yang tersedia. Menurut Piaget dalam Mgs. Nazarudin (2007:163) manajemen adalah serangkaian kegiatan yang didesain untuk mencapai tujuan organisasi dengan menggunakan sumber daya secara efisien dan efektif dan dilakukan dalam lingkungan yang senantiasa berubah dari waktu ke waktu. Efektif berarti tercapai tujuan yang ditetapkan dan efisien berarti mencapai tujuan dengan menggunakan sedikit mungkin sumber daya yang tersedia.

Menurut Piaget dalam Mgs. Nazarudin (2007:163) Manajemen merupakan serangkaian kegiatan yang didesain untuk mencapai tujuan organisasi dengan menggunakan sumber daya secara efisien dan efektif dan dilakukan dalam lingkungan yang senantiasa berubah dari waktu kewaktu.Efektif berarti tercapai tujuan yang ditetapkan dan efisien berarti mencapai tujuan dengan menggunakan sedikit mungkin sumber daya yang tersedia (Yanto, 2017). Manajemen adalah proses mendesain dan mengelola lingkungan dimana invidu mendesain bekerja sama dalam kelompok efektif dalam mencapai tujuan (Yanto M, 2017). Manajemen suatu upaya mengelola bekerja baik dalam kelompok maupun individu dengan harapan bisa efektif dan mencapai tujuan yang diharapkan. Bahan 
ajar adalah bahan-bahan atau materi pelajaran yang disusun secara sistematis, yang di gunakan dosen dan mahasiswa dalam proses pembelajaran (Yanto., 2020). Manajemen pembelajaran adalah kegiatan guru secara terprogram dalam mendesain instruksional,untuk membuat siswa belajar mengajar dikelas, yang mana menekankan pada penyediaan sumber belajar siswa di kelas (Yanto, 2018). Manajemen pendidikan yaitu meningkatkan produktivitas yang dilihat dari efisiensi penyelenggaraan pendidikan dan efektivitas pendidikan (Yanto., 2020).

Manajemen peserta didik bertujuan: (1) meningkatkan pengetahuan, keterampilan, dan psikomotorik peserta didik. (2) menyalurkan dan mengembangkan kemampuan umum (kecerdasan), bakat, dan minat peserta didik. (3) menyalurkan aspirasi, harapan dan memenuhi kebutuhan peserta didik. (4) peserta didik mencapai kebahagian dan kesejahtraan hidup yang lebih lanjut dapat blajar dengan baik dan mencapai cita-cita mereka (Bahrudin, 2014). Fungsi manajemen secara umum adalah sebagai wahana bagi peserta didik untuk mengembangkan diri seoptimal mungkin, baik yang berkenaan dengan dimensi-dimensi individu, sosial, aspirasi kebutuhannya dan dimensi potensi peserta didik lainnya.

Fungsi manajemen secara khusus yaitu: (1) Berkenaan dengan pengembangan individualitas peserta didik, ialah agar mereka dapat mengembangkan potensi-potensi individualitasnya tanpa terhambat. (2) Fungsi pengembangan berkenaan dengan fungsi sosial peserta didik ialah agar peserta didik dapat mengadakan sosialisasi dengan sebayanya, dengan orang tua dan keluarganya,dengan lingkungan sosialnya,dan lingkungan sosial masyarakatnya.(3) Fungsi berkenaan dengan penyaluran aspirasi dan harapan peserta didik,ialah agar peserta didik dapat menyalurkan hobi,kesenangan dan,minat.(4) Fungsi berkenaan dengan pemenuhan kebutuhan dan kesejahtraan peserta didik ialah agar peserta didik sejahtra dalam hidupnya (Bahrudin, 2014). Perinsip dasar manajemen peserta didik,adalah (a) siswa harus diperlakukan sebagai subjek bukan objek, (b) keadaan dan kondisi siswa sangat beragam, diinjau dari kondisi fisik, kemampuan intelektual, social ekonomi, minat dan sebagainya, (c) pada dasarnya siswahanya termotivasi belajar jika mereka menyenangi apa yang diajarkan, (d) pengembangan potensi tidak hanya menyangkut rana kognitif,tetapi juga afektif dan psikomotorik, tetapi juga afektif dan psikomotorik. 
Manajemen pendidikan secara umum sebagai pengaturan, penataan, pengelolaan pendidikan. Dalam arti umum ini, kegiatan yang dikatagorikan sebagai manajemen pendidikan adalah mengorganisasikan pendidikan, yaitu mengatur (menata) kegiatan penyelenggaraan pendidikan kedalam unit-unit (satuan) organisasi pendidikan menurut jenis (pendidikan umum, kedinasan, keagamaan, kejuruan) dan jenjang (pra sekolah, dasar, menengah, tinggi) (Yanto, 2020).

Berdasarkan uraian di atas, maka penulis dapat menyimpulkan bahwa pendidikan adalah usaha sadar atau kegiatan yang disengaja dilakukan untuk membimbing sekaligus mengarahkan anak didik menuju terbentuknya pribadi yang utama (insan kamil) meskipun berbeda redaksional namun secara essensial terdapat kesatuan unsur-unsur atau faktor-faktor yang terdapat di dalamnya yaitu bahwa pengertian pendidikan tersebut menunjukkan suatu proses bimbingan tuntunan atau pimpinan yang di dalamnya mengandung unsur-unsur seperti mendidik, anak didik, tujuan dan sebagainya (Uyoh Sadulloh, 2010).

Mutu adalah pemenuhan terhadap kebutuhan stakeholder, bersistem pencegahan, mempunyai standar tanpa cacat dan mempunyai ukuran harga ketidakpuasan. Mutu dalam bidang pendidikan meliputi mutu input, output dan outcomes. Input pendidikan dinyatakan bermutu jika setiap berproses, proses pendidikan bermutu apabila mampu mencipkan suasana yang pendidikan aktif, inovatif, kreatif, efektif dan menyenangkan. Output pendidikan dikatan bermutu jika hasil belajar akademik maupun non akademik siswa tinggi. Outcame dinyatakan bermutu apabila lulusan terserap didunia kerja, gaji wajar, semua pihak mengakui kehebatan lulusan (Yanto, 2019).

Peningkatan mutu Paud melibatkan enam faktor: 1. Kepemimpinan kepala Paud yang efektif 2. Siswa, anak sebagai pusat, sehingga kompetesi dan kemampuan siswa dapat digali 3. Pelitaban guru secara maksimal. 4. Kurikulum yang tetap tetapi dinamis, sehingga tujuan mutu dapat tercapai 5. Jaringan kerjasama tidak hanya terbatas pada lingkungan Paud dan masyarakat tetapi dengan organisasi lain, seperti perusahaan/instansi 6. Pimpinan dan karyawan harus menjadi satu tim yang utuh (time work) Yang saling membutuhkan dan saling mengisi kekurangan yang ada sehingga target (goals) akan tercapai dengan baik. 
Total Quality Management dalam pendidikan adalah filosofi perbaikan terus menerus dimana lembaga pendidikan menyediakan seperangkat sarana atau alat untuk memenuhi bahkan melampaui kebutuhan, keinginan dan harapan steakholder saat ini masa akan datang. Mutu adalah pelayanan yang diberikan kepada pemangku kepentingan, terdiri dari siswa, alumni, lulusan/pengguna industry dan orang tua siswa (Yanto.M.,2017). Sekolah bermutu adalah sekolah yang efektif, yang terdiri dari tatanan, proses dan out-put (Hoy, Wayne dan Cecil, 2008).

Usia dini merupakan momen yang amat penting bagi tumbuh kembang anak. Selain bagian otak anak mengalami perkembangan yang sangat pesat, usia dini juga sering disebut sebagai masa keemasan golden age, yaitu masa di mana semua stimulasi segenap aspek perkembangan mengambil peran penting bagi pertumbuhan anak selanjutnya. Setelah kelahiran sampai dengan usia sekitar 6 tahun, banyak terjadi perubahan yang luar biasa. Perubahan ini, misalnya sebutan yang yang pada awalnya adalah bayi kemudian menjadi anak-anak, munculnya refleks-refleks yang merupakan dasar kepekaan terhadap stimulus, munculnya celoteh yang akan berkembang menjadi kemampuan berkomunikasi (Wiwien Dinas Prastisti, 2007). Usia dini pada anak kadang-kadang disebut sebagai usia emas atau golden age. Masa-masa tersebut merupakan masa kretis dimana seorang anak membutuhkan rangsangan- rangsangan yang tepat untuk mencapai kematangan yang sempurna. Arti kretis adalah sangat mengarungi keberhasilan pada masa berikutnya.

Apabilah masa kretis ini tidak memperoleh rangsangan yang tepat dalam bentuk latihan atau proses belajar maka diperkirakan anak akan mengalami kesulitan pada masa-masa perkembangan berikutnya.misalnya, secara fsikologis anak sudah cukup berkembang dan mampu dilatih berbicara namun demikian rangsangan yang diperoleh dari lingkungan sangat kurang akibatnya anak mengalami kesulitan untuk berbicara. Usia dini juga merupakan masa penting sebagai landasan untuk perkembangan pada masa perkembangan berikutnya. Menurut freud, masa usia dini harus diberi landasan yang kuat agar terhindar dari gangguan kepribadian ataupun emosi. Lebih lanjut freud menyatakan bahwa gangguan-gangguan yang dialami pada masa dewasa dapat ditelusuri penyebabnya dengan melihat kehidupan pada masa kanakkanak. Misalnya. Orang yang agresif secara verbal, sering marah-marah, mengupat, ternyata pada usia-usia awalnya tidak memperoleh kepuasan terhadap kebutuhannya. Erikson menambahkan bahwa anak yang tidak 
mengalami dan memperoleh kepuasan dari kebutuhannya akan mengalami kegagalan untuk mengembangkan rasa percaya pada orang lain (Wiwien Dinas Prastisti, 2007). Pendidikan anak pada hakikatnya adalah pendidikan yang diselenggarakan tujuan untuk memfasilitasi pertumbuhan dan perkembangan anak secara menyeluruh atau menekankan pada pengembangan seluruh aspek kepribadian anak (Yanto, 2017).

Adapun tugas-tugas perkembangan anak usia dini 0-6 tahun adalah berjalan, belajar memakan makanan keras, belajar berbicara, belajar untuk mengaturgerak-gerik tubuh, belajar mengenal perbedaan jenis kelamin dengan ciri-cirinya, mencapai stabilitas fsiologis, membentuk konsep sederhana tentang realitas sosial dan fisik, belajar melibatkan diri secara emosional dengan orang tua, saudara maupun orang lain, belajar membentuk konsep tentang benar salah sebagai landasan membentuk nurani (Wiwien Dinas Prastisti, 2007). Anak usia dini mulai termotivasi untuk meniru prilaku orang tua (Yanto., 2017). Keluarga adalah merupakan lingkungan pertama bagi anak, di lingkungan keluarga pertama mendapatkan pengaruh, karena itu keluarga merupakan lembaga pendidikan tertua, yang bersifat informal dan kodrati. Lahirnya keluarga sebagai lembaga pendidikan semenjak manusia itu ada ayah, dan ibu didalam keluarga sebagai pendidikannya, dan anak sebagai terdidiknya. Islam mendorong untuk membentuk keluarga. Islam mengajak manusia untuk hidup dalam naungan keluarga, karena keluarga seperti gambaran kecil dalam kehidupan stabil yang menjadi pemenuhan keinginan manusia, tanpa menghilangkan kebutuhannya keluarga merupakan tempat fitrah yang sesuai dengan keinginan Allah.

\section{KESIMPULAN}

Berdasarkan hasil penelitian yang dilakukan di manajemen taman pendidikan anak usia dini Wijaya Kusuma menunjukkan bahwa pendidikan anak usia dini telah memenuhi ruang lingkup dalam manajemen peserta didik: (a) Perencanaan, seluruh aktivitas lembaga yang menyangkut apa yang harus dikerjakan,dimana dikerjakan, kapan akan dikerjakan,siapa yang mengerjakan dan bagaimana hal tersebut dikerjakan. (b) Organisasi, direncanakan untuk diselesaikan oleh anggota kelompok pekerjaan, penentuan hubungan pekerjaan diantara mereka dan pemberian lingkungan pekerjaan yang sepatutnya. (c) Pengarahan, merupakan dorongan yang akan memberikan motivasi dalam suatu organisasi. (d) Pengawasan untuk mengetahui realisasi perilaku personil dalam organisasi pendidikan dan apakah tingkat pencapaian tujuan pendidikan sesuai dengan yang dikehendaki. Pengawasan dilakukan untuk mengumpul data tentang penyelenggaraan kerjasama antar guru, kepala 
sekolah, konselor. (e) Mutu layanan yang diberikan kepada pemangku kepentingan terdiri dari siswa, alumni dan orang tua siswa Paud.

\section{REFERENSI}

Afrizal. (2015). Metode Penelitian Kualitatif Sebuah Upaya Mendukung Penggunaan Penelitian Kualitatif Dalam Berbagai Disiflin Ilmu. Rajawali Pers.

Agus Wibowo. (2012). Pendidikan Karakter Usia Dini. Celeban Timu.

Awaludin Pimay. (2013). Paradigma Humanis Strategi dan Dakwah. RajaGrafindo Persada.

Bahrudin. (2014). Manajemen peserta didik. Indeks.

Hoy,Wayne dan Cecil, G. M. (2008). Education Administration,Teori Research. Practice McGraw-Hill.

Uyoh Sadulloh. (2010). Pedagogik Ilmu Mendidik. Alfabeta.

Wiwien Dinas Prastisti. (2007). Psikologi Anak Usia Dini. PT Indiks.

Yanto, M., \& Fathurrochman, I. (2019). Manajemen Kebijakan Kepala Madrasah Dalam Meningkatkan Mutu Pendidikan. Jurnal Konseling Dan Pendidikan, 7(3), 123-130. http://doi.org/10.29210/138700.h.2

Yanto., M. (2017). Strategi Guru Dalam Pendidikan Pembelajaran Bahasa Indonesia di SDN 45 Curup. Ejournal.iainbengkulu, 5(2). http:ejournal.iainbengkulu.ac.id indexs.php/manhaj/oi/verb =listRecords \&metadata

Yanto., M. (2020). Manajemen Kepala Sekolah Dalam Menumbuhkan Kompetensi Sosial Di Madrasah Ibtidaiyah Muhammadiyah 10 Karang Anyar Rejang Lebong. Jurnal Ar- Riayah, 4(1). http://journal.iaincurup.ac.id/index.php/jpd

Yanto, M. (2017). Manajemen Perpustakaan Madrasah Ibtidaiyah Negeri 1 Rejang Lebong. Jurnal Ar- Riayah, 1(2), 189-204. doi:http://dx.doi.org/10.29240/indvli2319

Yanto, M. (2018). Manajemen dan Mutu Pembelajaran Bahasa Indonesia di SMPN 4 Rejang Lebong. Jurnal Ar-Riayah, 1(2), 192.

Yanto, M. (2019). Manajemen Pendidikan Pada Tadris Bahasa Indonesia STAIN Curup. Jurnal Manajemen Pendidikan, 3(1), 77-84. http://jurnal.iaincurup.ac.id/index php/jsmp/

Yanto, M. (2020). Manajemen Sekolah Dalam Pengelolaan Kegiatan Guru Bahasa Indonesia di Sekolah Dasar. Jurnal Estetik, 3(1), 15-26. doi:10.29240/estetik.V31i.1479 http://journal.iaincurup.ac.id/index. php/ estetik

Yanto M. (2017). Evulation of Quality Assurance Program. Jurnal Internasional Jurnal OF Human Capital Manajement, 1(2), 146-152. 